\title{
Competence in Continuous Cultures of Bacillus subtilis: Inhibition by Arginine and Reversal of the Inhibition by $\mathbf{M n}^{2+}$
}

\author{
By M. ESPINOSA, R. LÓPEZ, MARIA T. PÉREZ-UREÑA, E. GARCÍA \\ AND A. PORTOLES \\ Instituto de Inmunología y Biología Microbiana, Velázquez 144, Madrid 6, Spain
}

(Received 3 May 1976; revised 25 June 1976)

\section{SUMMARY}

Arginine inhibited the competence of Bacillus subtilis growing in a chemostat at a dilution rate of $0.277 \mathrm{~h}^{-1}$. The biosynthesis of competence-stimulating activity was only partially repressed. The inhibitory effect may be due to an alteration in the cell's capacity for being stimulated to competence and/or in its ability to take up DNA irreversibly. $\mathrm{MnSO}_{4}$ at $\mathrm{IO}^{-6} \mathrm{M}$ restored competence immediately.

\section{INTRODUCTION}

The frequency and the rate of appearance of competent cells in cultures of Bacillus subtilis is influenced by a variety of nutritional and physiological factors (Bott \& Wilson, 1967, I968; Spizizen, Reilly \& Evans, 1966). In the course of studies on factors that affect the expression of competence of $B$. subtilis growing in a chemostat (García, 1974; López, Tapia \& Portolés, 1975; Portolés, López \& Tapia, 1973), we made the puzzling observation that at a relatively fast growth rate [dilution rate $(D)=0.277 \mathrm{~h}^{-1}$ ], the steady-state level of competence was dramatically suppressed by the addition of arginine to the medium (López et al., I975); in contrast, slower growing cultures $\left(D=0.106 \mathrm{~h}^{-1}\right)$ showed no response to arginine (Portolés et al., 1973). We report here experiments designed to find out something about the mechanism of the arginine effect. We have tested specifically the possibility that arginine might block the production of a competence-stimulating activity(ies) (CSA) that can be detected in supernatants obtained from competent $B$. subtilis cultures (Joenje, Gruber \& Venema, 1972).

\section{METHODS}

Strains. Bacillus subtilis AR I T, a prototrophic strain, was used as recipient for transfections. It was obtained by transforming strain SB25 (hisB2 $\operatorname{trp} C 2$ ) with DNA isolated from $B$. subtilis I68 wild type. Bacillus subtilis MCB was the indicator bacterium and SPPI phage was used as a source of DNA for transfection (both strains were kindly provided by Professor T. A. Trautner). Strain 2GB (tyr thy) (kindly provided by Professor G. Venema) was used for the isolation of ${ }^{3} \mathrm{H}$-labelled transfecting DNA.

$D N A$. Transfecting DNA was obtained by the method of Rottländer \& Trautner (1970). Specific activity of ${ }^{3} \mathrm{H}$-labelled DNA was $\mathrm{I} \cdot 3 \times 10^{5}$ counts $\mathrm{min}^{-1} \mu \mathrm{g}^{-1}$.

Transfection. This was performed as described previously (López et al., 1975).

Media and growth conditions. Bacillus subtilis ARIT was grown in the minimal glucose medium described by Bott $\&$ Wilson (1968) and the conditions for continuous culture have been described (López et al., I975; Portolés et al., 1973); a dilution rate of $0.277 \mathrm{~h}^{-1}$ was used. 


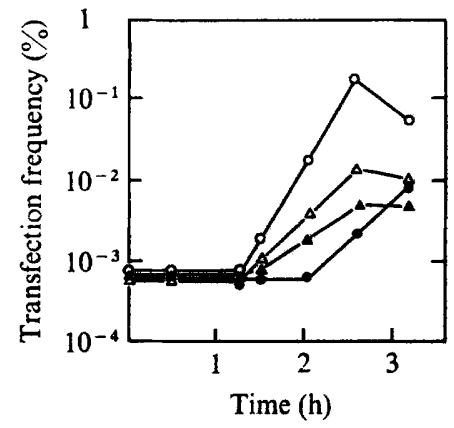

Fig. I

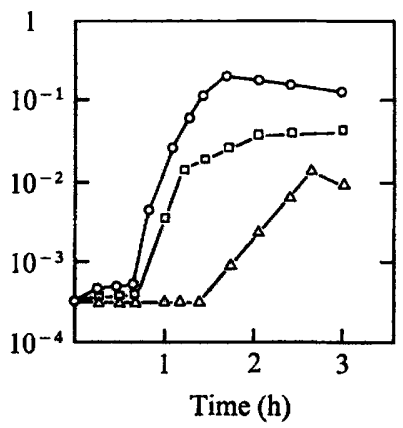

Fig. 2

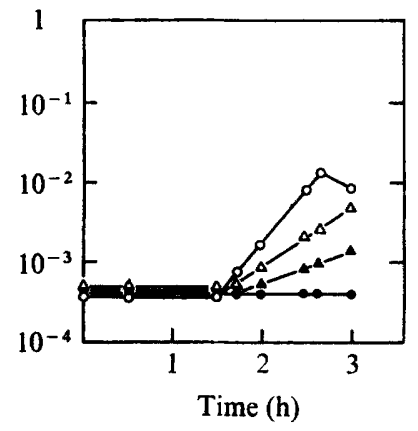

Fig. 3

Fig. I. Stimulation of competence development of physiologically low-competent (PLC) cells. At zero time, PLC cells, obtained as described in Methods, were suspended at an $E_{500}$ of 0.08 in supernatants obtained from: highly competent batch cultures $(O)$; continuous cultures without arginine $(\triangle)$; and continuous cultures with arginine $(\Delta)$. Control: PLC cells suspended in fresh BW medium (O). Samples were removed at intervals and transfection frequencies were assayed.

Fig. 2. Stimulation of competence development by culture supernatants obtained from highly competent batch cultures. PLC cells $(O)$; CC cells, from a continuous culture without arginine $(\square)$; A cells, from a continuous culture with arginine $(\triangle)$. CC cells came from a continuous culture which had a transfection frequency of $7.3 \times 10^{-2} \%$; this dropped about 2 log units after washing. A cells came from a continuous culture which had a transfection frequency of $3.9 \times 10^{-4} \%$. The assay conditions were as in Fig. I.

Fig. 3. Stimulation of the competence of A cells, isolated from continuous culture in the presence of arginine. Cells were harvested by centrifuging and suspended at an $E_{500}$ of 0.08 in supernatants obtained from: highly competent batch cultures $(\odot)$; continuous cultures without arginine $(\triangle)$; and continuous cultures with arginine $(\Delta)$. Control: A cells in fresh BW medium (O). Samples were removed at intervals and transfection frequencies were assayed.

Binding of DNA to cells. Bacteria from continuous culture, growing with or without arginine, were tested for their ability to bind transfecting SPPI $\left[{ }^{3} \mathrm{H}\right] \mathrm{DNA}$ by the methods of Joenje \& Venema (1975) and Seto \& Tomasz (1974).

Stimulation of the competence development. Physiologically low-competent (PLC) cells and culture supernatants were obtained according to Joenje et al. (1972). PLC cells, as well as those obtained from continuous culture, were harvested by centrifuging, washed twice in prewarmed minimal medium and resuspended at an extinction $\left(E_{500}\right)$ of 0.08 in either fresh Bott \& Wilson's minimal medium (BW) or culture fluids obtained as previously described (García, 1974). The cells were incubated at $37^{\circ} \mathrm{C}$ for various times and then transfected unless stated otherwise.

\section{RESULTS AND DISCUSSION}

We have recently found (Espinosa et al., I976) a relationship between the maximum yield of transfectants after 150 min of stimulation of PLC cells and the amount of CSA present in the culture fluids. Culture supernatants of bacteria grown in the chemostat, with or without arginine, were tested for their ability to stimulate PLC cells. Supernatants obtained from arginine-containing cultures had the lower CSA (Fig. I). Cells incubated either in supernatants obtained from highly competent batch cultures or in fresh medium were used as controls.

To test the capacity of bacteria growing in the chemostat, in the absence (CC cells) or in the presence (A cells) of arginine, to react with CSA, we resuspended the bacteria in supernatants obtained from highly competent batch cultures and, after various times of incuba- 
Table I. DNA-binding capacity of cells grown in the presence $(A)$ or absence $(C C)$ of arginine, using SPPI phage as a source of $\left[{ }^{3} H\right] D N A$

$\begin{array}{lcc}\text { Cells } & \begin{array}{c}\text { Transfectants } \\ \mathrm{ml}^{-1}\end{array} & \begin{array}{c}\left.{ }^{3} \mathrm{H}\right] \mathrm{DNA} \text { bound } \\ \left(\mu \mathrm{g} / 10^{10} \text { cells }\right)\end{array} \\ \mathrm{CC} & 2.8 \times 10^{5} & 8.0^{*} \\ \mathrm{~A} & 1.3 \times 10^{2} & 1 \cdot 1 * \\ \text { CC } & 2.5 \times 10^{5} & 7 \cdot 2 \dagger \\ \text { A } & 1.2 \times 10^{2} & 1 \cdot 2 \dagger\end{array}$

* Tested as described by Joenje \& Venema (1975).

$\uparrow$ Tested as described by Seto \& Tomasz (1974).

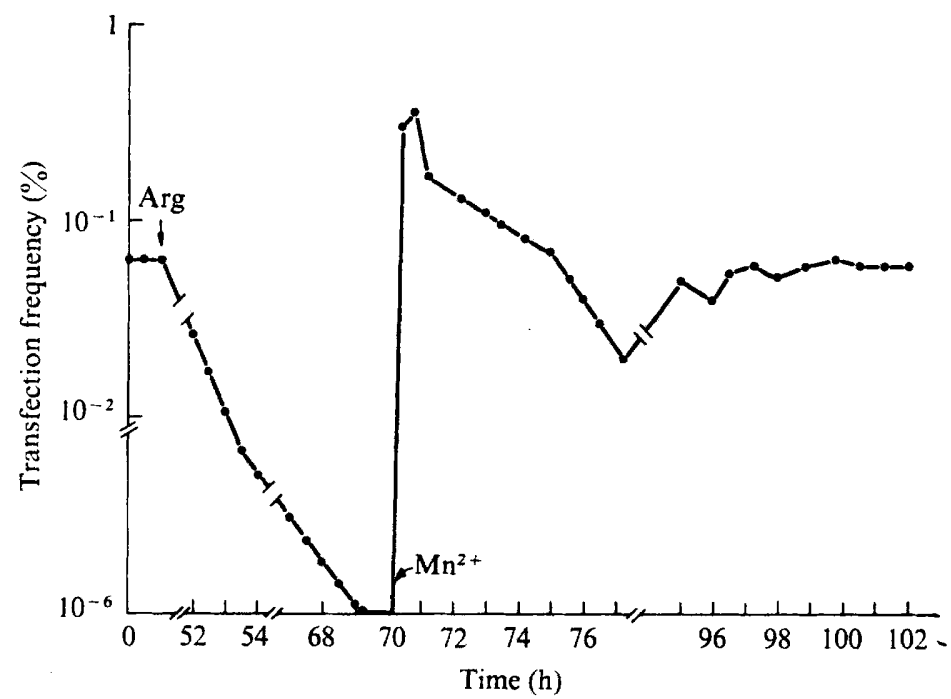

Fig. 4. Recovery of the initial level of competence in arginine-inhibited continuous cultures on addition of $\mathrm{MnSO}_{4}$. Zero time was taken as the time when the culture reached a constant level of competence. After $48 \mathrm{~h}$, arginine ( $100 \mu \mathrm{g} \mathrm{ml}^{-1}$ ) was continuously added to the chemostat. At $70 \mathrm{~h}$, ${ }_{10}^{-6} \mathrm{M}_{-}-\mathrm{MnSO}_{4}$ was also added continuously to the chemostat. Samples were removed at intervals and transfection frequencies were assayed.

tion, the transfection frequencies were determined (Fig. 2). PLC cells were used as a control. With PLC and CC cells there was an initial lag in the response. This lag was much longer (about $90 \mathrm{~min}$ ) with A cells.

To exclude the possibility that the lag shown by A cells was due to a specific response to culture supernatants obtained from highly competent batch cultures, we tested A cells with supernatants from different sources. The arginine-grown cells reacted to CSA only after a prolonged lag (Fig. 3). Nevertheless, the cells did respond to the stimulating effect of CSA. When CC cells were tested in the same conditions there was no such lag (data not shown).

From Figs 2 and 3, we conclude that arginine mainly affects the cellular response to stimulation by CSA, while the biosynthesis of CSA is relatively less affected. Nevertheless, in the chemostat, the dramatic inhibition of competence by arginine (reduced from $10^{-1} \%$ to $10^{-4}$ to $10^{-6} \%$; López et al., 1975) cannot be explained exclusively in terms of an inhibition in either the production of CSA or in the cellular reactivity to the CSA. Growth in the presence of arginine seems to interfere with an early stage of transformation, presumably 
with a stage in competence, since arginine-grown bacteria only bind about $15 \%$ of the amount of DNA that is bound by comparable bacteria grown without arginine (Table 1 ).

When we prepared the BW medium with distilled water instead of demineralized and distilled water, the inhibitory effect of the arginine at $D=0.277^{\mathrm{h}^{-1}}$ on competence was no longer detectable, suggesting that some cations could be involved in the role played by the arginine. It is known that $\mathrm{Mn}^{2+}$ is needed for the activity of the arginase. Hanson \& Cox (I967) reported that arginine causes repression of aconitase in B. subtilis growing in a chemostat when it is added to a minimal glucose medium. If competence in $B$. subtilis needs an intact tricarboxylic acid cycle (Spizizen et al., 1966) we might expect that the addition of $\mathrm{Mn}^{2+}$ to the chemostat would produce an increase of the competence level as a consequence of the degradation of the arginine by the arginase. Bacteria were grown in continuous culture until they had been in steady state (constant level of competence) for $48 \mathrm{~h}$. Arginine (to $100 \mu \mathrm{g} \mathrm{ml}^{-1}$ ) was then continuously added to the chemostat as previously described (Portolés et al., 1973). Competence dropped by $5 \log$ units in about $48 \mathrm{~h}$. A dramatic increase in competence was detected 10 min after $\mathrm{MnSO}_{4}$ was added to the chemostat and the initial level of competence was restored after about I day (Fig. 4). Other cations, such as $\mathrm{Mg}^{2+}$ or $\mathrm{Zn}^{2+}$, were ineffective. From these results, it seems possible that the arginine effect may indeed indicate some involvement of the tricarboxylic acid cycle in the development of competence, although we cannot exclude the possibility that a low level of $\mathrm{Mn}^{2+}$ is specifically required for competence (Kelly \& Pritchard, 1965) and that arginine removes it by chelation.

An unexplained feature of these observations is why only cells growing with a certain dilution rate $\left(D=0.277 \mathrm{~h}^{-1}\right)$ respond to arginine in the growth medium (López et al., 1975). The development or 'unmasking' of DNA binding sites at the cells' surfaces (Seto, López \& Tomasz, 1975) may occur through a variety of metabolic pathways dependent on their specific physiological condition or the type of their surface structures.

We thank Professor A. Tomasz for the critical reading of the manuscript. We wish to acknowledge the technical assistance of Miss M. T. Alda and M. L. del Pozo.

\section{REFERENCES}

Bort, K. F. \& Wuson, G. A. (1967). Development of competence in the Bacillus subtilis transformation system. Journal of Bacteriology 94, 562-570.

BotT, K. F. \& WrLson, G. A. (I968). Metabolic and nutritional factors influencing the development of competence for transfection of Bacillus subtilis. Bacteriological Reviews 32, 370-378.

Espinosa, M., García, E., PÉrez-Ureña, M. T., Ferrnaud, J. M. \& Portolés, A. (I976). Competence development for transfection stimulated by culture fluids of Bacillus subtilis. Antonie van Leeuwenhoek 42, 95-99.

GARCÍA, E. (1974). Caracteristicas fisiológicas del estado de competencia en sistemas transfectantes de Bacillus subtilis. Doctorate thesis, Faculty of Science, Madrid University.

Hanson, R. S. \& Cox, D. P. (1967). Effect of different nutritional conditions on the synthesis of tricarboxylic acid cycle enzymes. Journal of Bacteriology 93, 1777-1787.

JoENJe, H. \& VeNEMA, G. (1975). Different nuclease activities in competent and non-competent Bacillus subtilis. Journal of Bacteriology 122, 25-33.

JoENJE, H., GRUBER, M. \& VENEMA, G. (1972). Stimulation of the development of competence by culture fluids in Bacillus subtilis transformation. Biochimica et biophysica acta 262, 189-199.

Kelly, M. S. \& Pritchard, R. H. (1965). Unstable linkage between genetic markers in transformation. Journal of Bacteriology 89, 1314-1321.

López, R., TAPIA, A. \& Portolés, A. (I975). The influence of glutamic acid and arginine on the competence of Bacillus subtilis growing in a chemostat. Molecular and General Genetics 136, 87-94.

Portolks, A., López, R. \& TAPIA, A. (1973). An approach to the study of the competence regulation in Bacillus subtilis growing in a chemostat. In Bacterial Transformation. pp. 65-80. Edited by L. J. Archer. London: Academic Press. 
ROTTLÄNDER, E. \& TRAUTNER, T. A. (1970). Genetic and transfection studies with Bacillus subtilis phage SP50. I. Phage mutants with restricted growth on Bacillus subtilis strain I68. Molecular and General Genetics 108, 47-60.

Seto, H. \& TomASz, A. (1974). Early steps in DNA-binding and uptake during genetic transformation of pneumococci. Proceedings of the National Academy of Sciences of the United States of America $7 \mathbf{r}$, I 493-I 498 .

Seto, H., LÓPEZ, R. \& Tomasz, A. (1975). Cell surface-located deoxyribonucleic acid receptors in transformable pneumococci. Journal of Bacteriology 122, $1339-1350$.

Spizizen, J., Reilly, B. E. \& Evans, A. H. (I966). Microbial transformation and transfection. Annual Review of Microbiology 20, 371-400. 